\title{
Dynamics of early juvenile winter flounder predation risk on a North West Atlantic estuarine nursery ground
}

\author{
John P. Manderson ${ }^{1, *}$, Jeffrey Pessuttii ${ }^{1}$, Patricia Shaheen ${ }^{2}$, Francis Juanes ${ }^{3}$ \\ ${ }^{1}$ NOAA/National Marine Fisheries Service, Ecosystem Processes Division, Behavioral Ecology Branch, \\ James J. Howard Marine Sciences Laboratory, Highlands, New Jersey 07732, USA \\ ${ }^{2}$ Biological Sciences Department, Wagner College, One Campus Road, Staten Island, New York 10301, USA \\ ${ }^{3}$ Department of Natural Resources Conservation, University of Massachusetts, Amherst, Massachusetts 01003-9285, USA
}

\begin{abstract}
In an effort to determine the characteristics of estuarine habitats suitable for early juvenile winter flounder Pseudopleuronectes americanus survivorship, we examined piscivorous fish distributions and diets, and flounder predation risk along estuarine gradients in the Navesink River/Sandy Hook Bay estuarine system, New Jersey, USA. Demersal fish, striped searobin Prionotus evolans and summer flounder Paralichthys dentatus, were more important predators of winter flounder than pelagic fish (Pomatomus saltatrix, Cynoscion regalis, Morone saxatilis) based on diet analysis of 4 yr of gill (1998 and 1999) and trammel net (2001 and 2002) fish collections. From April through June newly settled winter flounder $<20 \mathrm{~mm}$ standard length (SL) were eaten by striped searobin that were common in habitats with salinities $\geq 20 \%$. Fish $>20 \mathrm{~mm}$ standard length (SL) were consumed by summer flounder in shallow habitats in June and July. In May and June tethering experiments, Age0 winter flounder predation risk was high in habitats with salinities $>19 \%$ and temperatures $>20^{\circ} \mathrm{C}$. In $3 \mathrm{yr}$, salinities were $<20 \%$ in the upstream reach of estuary which probably served as a predator refuge for settling flounder. During 2002, however, historically low freshwater discharge associated with a spring drought produced high salinities $\geq 20 \%$ in upstream habitats where searobins ate large numbers of settling winter flounder and predation risk was high. These results suggest that the volume of estuarine habitat suitable for early juvenile flounder survivorship is determined, in part, by predator and prey responses to spatially dynamic physico-chemical gradients. Because gradient dynamics are controlled by climate forcing, climate variation may cause nursery habitat volumes to contract or expand resulting in variation in the local production of Age-0 recruits.
\end{abstract}

KEY WORDS: Nursery habitat dynamics · Predation risk · Essential fish habitat

\section{INTRODUCTION}

For many demersal fish, recruitment variability is generated in early life history and population size is related to the availability of suitable nurseries (Sissenwine 1984, MacCall 1990, van der Veer et al. 2000a). Predation plays an important role in regulating nursery habitat suitability and population size (van der Veer et al. 2000b, Wennhage \& Phil 2001, Webster 2002). Predation rates on tropical reef fish are highest during the first days to weeks following larval settlement and are strongly affected by habitat variation (Hixon \& Jones, 2005 and references therein). Early post-settlement mortality is difficult to measure for mobile species in turbid, temperate environments but appears to regulate temperate populations (van der Veer et al. 2000a, Wennhage \& Phil 2001, Manderson et al. 2003).

Predation is extremely variable but can be structured in systems with strong habitat gradients (Post et al. 1998, Overholtzer-McLeod 2004). In temperate estuaries, sea- 
sonal and upstream changes in temperature and salinity are reflected in biological community variation (Jung \& Houde 2003, Martino \& Able 2003). Conceivably, species-specific responses to these physico-chemical gradients determine times and regions of predator-prey habitat overlap. Within regions of overlap, finer scale biological (e.g. alternative prey) and structural characteristics (e.g. habitat complexity) as well as body size constraints, further modify predation risk (Murdoch et al. 1975, Sogard 1997, Forrester \& Steele 2004).

Northwest Atlantic estuaries serve as winter flounder Pseudopleuronectes americanus nurseries (see Pereira et al. 1999 for review). During winter and spring, adults spawn demersal eggs that hatch pelagic larvae. Larvae settle near spawning grounds in spring and early summer (Sogard et al. 2001, Manderson et al. 2003). Juveniles are generally most abundant in upstream estuarine reaches (Pearcy 1962, Armstrong 1997, Meng \& Powell 1999, Stoner et al. 2001). Upstream distributions result from early post-settlement mortality and/or emigration rather than larval supply in some estuaries (Pearcy 1962, Curran \& Able 2002, Manderson et al. 2003). Most studies of juvenile flounder mortality have emphasized the role of sand shrimp predators (e.g. Crangon septemspinosa; Bertram \& Leggett 1994, Taylor \& Collie 2003). However, Taylor (2005) demonstrated that shrimp predation was low in a mid-Atlantic estuary compared with New England nurseries and suggested that shrimp predation rates increase with increasing latitude. If this is the case, fish predation may be an important mechanism regulating habitat suitability and population size in the southern part of the species range. Fish are known to consume Age-0 winter flounder (reviewed in Pereira et al. 1999) but factors controlling fish predation on winter flounder nurseries have not been examined.

Our goal in this study was to describe the spatial dynamics of habitat suitability for early juvenile winter flounder survivorship on a mid-Atlantic estuarine nursery ground. We used gill net, trammel net, and beam trawl surveys to identify seasonal, spatial, and sizedependent patterns of flounder consumption by fish predators. To quantify relationships between predation risk, variations in the predator field, and estuarine gradients during flounder settlement, we conducted simultaneous tethering experiments and net surveys throughout the nursery.

\section{MATERIALS AND METHODS}

Study area. We performed this study in the Navesink River/Sandy Hook Bay estuarine system (NSBES), New Jersey, USA which is similar to many riverine estuaries in the Mid-Atlantic Bight and contributes to the winter flounder stock (present Fig. 1; Sogard et al. 2001). The
NSBES connects to the Atlantic Ocean at the Sandy Hook peninsula and extends $20 \mathrm{~km}$ south and west to the confluence of the Navesink and Swimming Rivers. Maximum depths range from $15 \mathrm{~m}$ in Sandy Hook Bay to $\sim 3 \mathrm{~m}$ in the Navesink River. The Swimming River is the primary freshwater source for the Navesink and salinity can range from $\sim 10 \%$ in the western Navesink to $\sim 30 \%$ in the northeastern part of Sandy Hook Bay. Water temperatures can exceed $30^{\circ} \mathrm{C}$ in the river during summer and the tidal range averages $1.4 \mathrm{~m}$ (see also Stoner et al. 2001, Manderson et al. 2002, 2003).

Surveys of predators. We used gill net and trammel net surveys to identify seasonal, spatial, and sizedependent patterns of Age-0 flounder consumption by, and distributions of, piscivorous fish (Table 1, Fig. 1). Gill nets (46 m long $\times 2.5 \mathrm{~m}$ deep: $7.6 \mathrm{~m}$ panels of 1.3 , $1.9,2.5,3.8,5.1$ and $7.6 \mathrm{~cm}$ mesh) were fished for $2 \mathrm{~h}$ fortnightly at 14 shallow stations from May through October 1998 and 1999. We set the nets $\sim 1 \mathrm{~h}$ before high tides occurring $<4 \mathrm{~h}$ after sunrise.

In 2001 and 2002, we used trammel nets (100 m long $\times 2 \mathrm{~m}$ deep, $5 \mathrm{~cm}$ inner mesh, $36 \mathrm{~cm}$ nylon walls) to more effectively capture important demersal predators of winter flounder identified in gill net surveys (Tables 1 \& 2). The nets were fished weekly for $2 \mathrm{~h}, 2 \mathrm{~h}$ after sunrise during winter flounder settlement (May and June). In 2001 we continued the surveys fortnightly through mid-October. Three stations randomly selected from grids within each of 6 sectors of the NSBES were sampled in each 2001 survey (18 Stns survey ${ }^{-1}$; Fig. 1). In 2002, we fished the nets at the 12 stations where we performed tethering experiments (see below).

During surveys, we measured depths with an electronic depth finder $(\mathrm{cm})$, and bottom water temperatures $\left({ }^{\circ} \mathrm{C}\right.$ ) and salinities $(\%$ ) with a probe (Yellow Springs Instruments). In 2001 and 2002 we used a $1 \mathrm{~m}$ beam trawl ( $3 \mathrm{~mm}$ mesh liner; tow speed $=1 \mathrm{~m} \mathrm{~s}^{-1}$, duration $=30 \mathrm{~s}$ ) to measure flounder and alternative prey densities following the recovery of each trammel net.

We counted and measured (length, mm) fish collected in gill nets, trammel nets, and beam trawls. Catch per unit effort (CPUE) was calculated as the number of individuals captured $\mathrm{h}^{-1}$ in nets, and $10 \mathrm{~m}^{-2}$ of tow in beam trawls. We removed and preserved (10\% formalin) stomachs of fish collected in nets for diet analysis. Diet items were identified to species, counted, weighed (wet weight, g), and length was measured $(\mathrm{mm})$ when possible.

We summarized patterns of habitat use for flounder predators collected in nets and identified in diet analysis with descriptive discriminant analysis (DA) using backward stepwise selection (Ade-4 library in R: Thioulouse et al. 2004, available at http://pbil.univ-lyon1.fr/ADE-4/ adelist.html; R Development Core Team 2004). We analyzed gill net and trammel net surveys separately. Spe- 

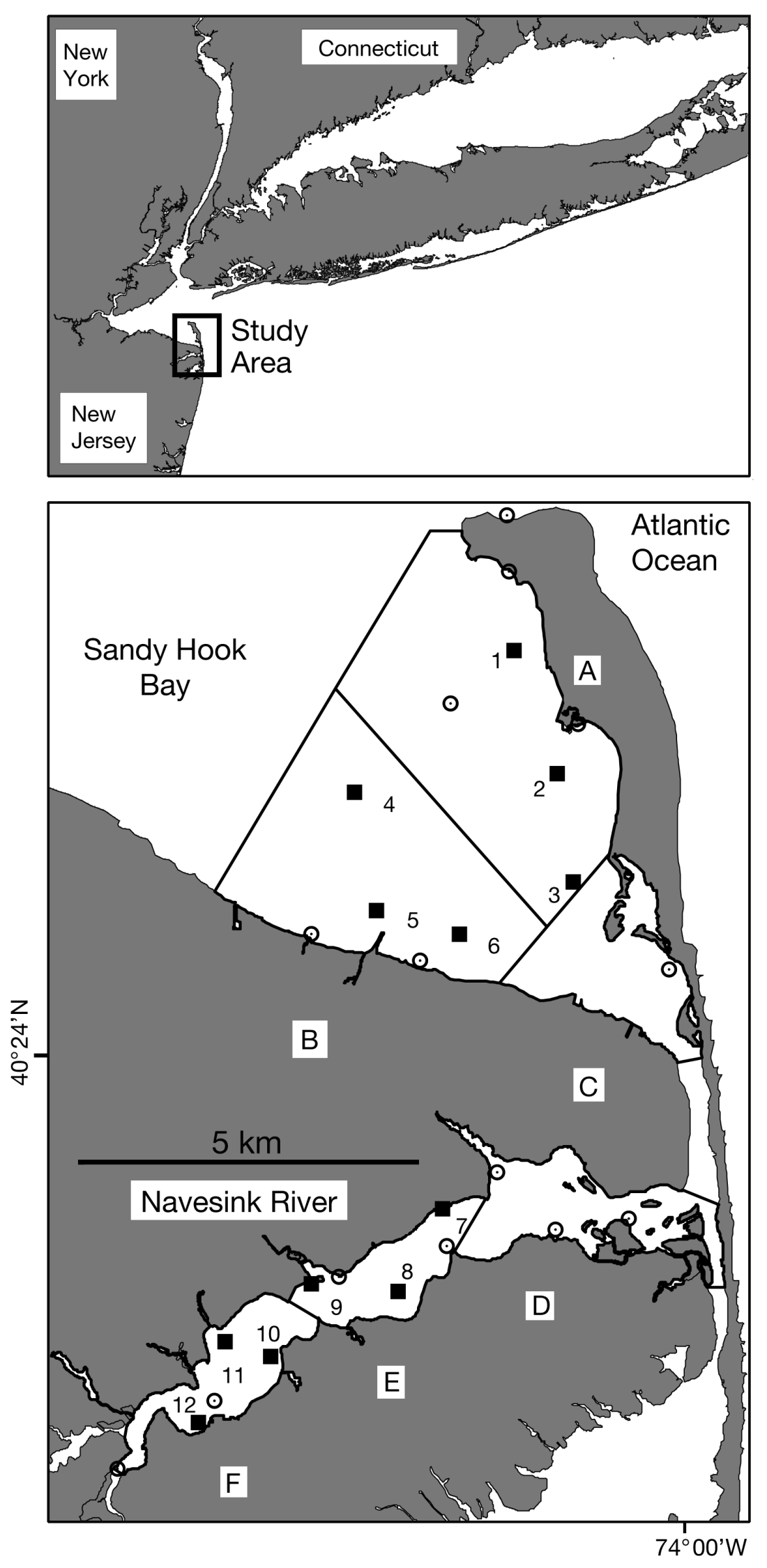

Fig. 1. Location of the study area on the Mid-Atlantic coast of the USA and of stations in the Navesink River/Sandy Hook Bay estuarine system, New Jersey, where predator surveys and tethering were performed. Gillnets were fished at 14 shallow water stations $(\odot)$ in 1998 and 1999. Trammel nets were fished at stations selected at random within 3 sectors nested within the bay (Sectors A, B, C) and the river (Sectors D, E, F) in 2001. In 2002 trammel nets were fished at 12 fixed stations where tethering was also performed

cies presence in each net served as dependent variables because most predators were schooling and individual fish were not independent. Since beam trawl collections were made with trammel net surveys, we included Age-0 winter flounder presence in trawls in the DA of 2001 and 2002 data to summarize predator-prey habitat overlap. The independent variables were year, day of the year, distance upstream ( $\mathrm{km}$ from the tip of Sandy Hook; Fig 1), temperature $\left({ }^{\circ} \mathrm{C}\right)$, and salinity (\%o). We included depth in the DA of 2001 and 2002 data because a wide range of depths was sampled (Table 1). DA models were tested using Monte-Carlo tests with 1000 permutations.

We calculated probabilities of occurrence of dominant flounder predators during winter flounder settlement with respect to salinity and temperature using logistic generalized additive models (GAM; Wood \& Augustin 2002, R Development Core Team 2004). Predator presence/absence in trammel nets fished from late April through June 2001 and 2002 served as dependent variables. We used trammel net data because the surveys were conducted weekly during flounder settlement and collected large numbers of demersal flounder predators (see 'Results'). Cubic spline smooths of temperature, salinity, and the interaction were included in initial models. We performed backward selection of significant terms $\left(\chi^{2}, p \leq 0.05\right)$ using analysis of deviance of nested models (Venables \& Ripley 1997). We replaced smoothed terms with linear terms if nonparametric degrees of freedom were close to 1 and deviance plots indicated that dependent and independent variables were linearly related. 
Table 1. Surveys used for analyses of distributions and diets of piscine predators of juvenile winter flounder Pseudopleuronectes americanus in the Navesink River / Sandy Hook Bay estuarine system. Fixed stations were used in all years except 2001 when stations were randomly selected within each of 6 sectors for each survey (see Fig.1). River discharge data from http://nwis.waterdata.usgs. gov/nj/nwis/monthly/?site_no=01407500\&agency_cd=USGS. Mean discharge during April and May from 1923 to $2003=2.24 \mathrm{~m}^{3} \mathrm{~s}^{-1}$

\begin{tabular}{|c|c|c|c|c|c|c|c|}
\hline Year & Gear & $\begin{array}{l}\text { Stations } \\
(\mathrm{N})\end{array}$ & $\begin{array}{c}\text { Depth } \\
\text { (m, range) }\end{array}$ & $\begin{array}{l}\text { Swimming River discharge } \\
\text { April-May }\left(\mathrm{m}^{3} \mathrm{~s}^{-1}\right)\end{array}$ & $\begin{array}{l}\text { Duration } \\
\text { (mo/d) }\end{array}$ & Frequency & $\begin{array}{l}\text { Nets set } \\
(\mathrm{N})\end{array}$ \\
\hline 1998 & Gillnet & 14 & $2.2(1.5-3.0)$ & 4.98 & $5 / 8-11 / 6$ & Fortnightly & 182 \\
\hline 1999 & Gillnet & 14 & $2.2(1.5-3.0)$ & 1.28 & $5 / 12-11 / 10$ & Fortnightly & 182 \\
\hline $2001^{\mathrm{a}}$ & Trammel net & 18 & $3.2(0.3-8.2)$ & 1.46 & $4 / 19-10 / 17$ & $\begin{array}{l}\text { Weekly to } 6 / 18 \\
\text { then fortnightly }\end{array}$ & 330 \\
\hline $2002^{a, b}$ & Trammel net & 12 & $4.0(0.8-8.2)$ & 0.26 & $4 / 22-6 / 21$ & Weekly & 108 \\
\hline
\end{tabular}

Table 2. Fish collected in gillnet (1998 and 1999) and trammel net (2001 and 2002) surveys and frequency of juvenile winter flounder Pseudopleuronectes americanus in their diets (Flounder \%). Gillnet collections were dominated by pelagic bluefish and weakfish as well as striped bass that consumed flounder infrequently. Demersal striped searobin and summer flounder predators were abundant in trammel nets and frequently consumed Age- 0 winter flounder. $\mathrm{N}$ stom. = number of stomachs examined

\begin{tabular}{|c|c|c|c|c|c|c|c|c|c|}
\hline \multirow{2}{*}{$\begin{array}{l}\text { Scientific } \\
\text { name }\end{array}$} & \multirow{2}{*}{$\begin{array}{l}\text { Common } \\
\text { name }\end{array}$} & \multirow{2}{*}{$\mathrm{N}$} & \multirow{2}{*}{$\begin{array}{l}-1998- \\
\text { Flounder (\%) } \\
\text { (N stom.) }\end{array}$} & \multirow{2}{*}{$\mathrm{N}$} & \multirow{2}{*}{$\begin{array}{l}-1999- \\
\text { Flounder (\%) } \\
\text { (N stom.) }\end{array}$} & \multirow{2}{*}{$\mathrm{N}$} & \multirow{2}{*}{$\begin{array}{l}-2001- \\
\text { Flounder (\%) } \\
\text { (N stom.) }\end{array}$} & \multirow{2}{*}{$\mathrm{N}$} & \multirow{2}{*}{$\begin{array}{l}-2002- \\
\text { Flounder (\%) } \\
\text { (N stom.) }\end{array}$} \\
\hline & & & & & & & & & \\
\hline $\begin{array}{l}\text { Prionotus } \\
\text { evolans }\end{array}$ & $\begin{array}{l}\text { Striped } \\
\text { searobin }\end{array}$ & 83 & $\begin{array}{l}33.3 \\
(75)\end{array}$ & 46 & $\begin{array}{l}6.9 \\
(29)\end{array}$ & 975 & $\begin{array}{c}15.9 \\
(482)\end{array}$ & 284 & $\begin{array}{l}23.4 \\
(248)\end{array}$ \\
\hline $\begin{array}{l}\text { Paralichthys } \\
\text { dentatus }\end{array}$ & $\begin{array}{l}\text { Summer } \\
\text { flounder }\end{array}$ & 14 & $\begin{array}{l}11 \\
(9)\end{array}$ & 13 & $\begin{array}{c}12.5 \\
(8)\end{array}$ & 284 & $\begin{array}{c}16.8 \\
(173)\end{array}$ & 24 & $\begin{array}{l}41.2 \\
(17)\end{array}$ \\
\hline $\begin{array}{l}\text { Morone } \\
\text { saxatilis }\end{array}$ & $\begin{array}{l}\text { Striped } \\
\text { bass }\end{array}$ & 68 & $\begin{array}{l}3.8 \\
(52)\end{array}$ & 26 & $\begin{array}{l}4.8 \\
(21)\end{array}$ & 2 & $\begin{array}{c}0 \\
(1)\end{array}$ & 0 & 0 \\
\hline $\begin{array}{l}\text { Cynoscion } \\
\text { regalis }\end{array}$ & Weakfish & 136 & $\begin{array}{l}1.0 \\
(96)\end{array}$ & 245 & $\begin{array}{c}0 \\
(121)\end{array}$ & 8 & $\begin{array}{c}33.3 \\
(3)\end{array}$ & 1 & $\begin{array}{c}0 \\
(1)\end{array}$ \\
\hline $\begin{array}{l}\text { Pomatomus } \\
\text { saltatrix }\end{array}$ & Bluefish & 699 & $\begin{array}{c}0.6 \\
(308)\end{array}$ & 1027 & $\begin{array}{c}1.0 \\
(395)\end{array}$ & 55 & $\begin{array}{c}0 \\
(25)\end{array}$ & 10 & $\begin{array}{c}0 \\
(2)\end{array}$ \\
\hline $\begin{array}{l}\text { Scophthalmus } \\
\text { aquosus }\end{array}$ & $\begin{array}{l}\text { Windowpane } \\
\text { flounder }\end{array}$ & 0 & 0 & 3 & $0(3)$ & 83 & $\begin{array}{c}0 \\
(39)\end{array}$ & 4 & 0 \\
\hline $\begin{array}{r}\text { Raja } \\
\text { spp. }\end{array}$ & Skates & 0 & 0 & 0 & 0 & 20 & $\begin{array}{c}0 \\
(18)\end{array}$ & 7 & $\begin{array}{c}0 \\
(7)\end{array}$ \\
\hline $\begin{array}{l}\text { Pseudopleuronectes } \\
\text { americanus }\end{array}$ & $\begin{array}{l}\text { Winter } \\
\text { flounder }\end{array}$ & 0 & 0 & 0 & 0 & 27 & $\begin{array}{c}0 \\
(27)\end{array}$ & 0 & 0 \\
\hline $\begin{array}{l}\text { Menticirrhus } \\
\text { saxatilits }\end{array}$ & $\begin{array}{l}\text { Northern } \\
\text { kingfish }\end{array}$ & 20 & $\begin{array}{c}0 \\
(12)\end{array}$ & 0 & 0 & 0 & 0 & 0 & 0 \\
\hline $\begin{array}{l}\text { Stonglyura } \\
\text { marina }\end{array}$ & $\begin{array}{l}\text { Atlantic } \\
\text { needlefish }\end{array}$ & 2 & $\begin{array}{c}0 \\
(2)\end{array}$ & 16 & $\begin{array}{c}0 \\
(7)\end{array}$ & 0 & 0 & 0 & 0 \\
\hline $\begin{array}{l}\text { Synodus } \\
\text { foetens }\end{array}$ & $\begin{array}{l}\text { Inshore } \\
\text { lizardfish }\end{array}$ & 4 & $\begin{array}{c}0 \\
(4)\end{array}$ & 1 & $\begin{array}{c}0 \\
(1)\end{array}$ & 0 & 0 & 0 & 0 \\
\hline $\begin{array}{l}\text { Tautoga } \\
\text { onitis }\end{array}$ & Tautog & 1 & $\begin{array}{c}0 \\
(1)\end{array}$ & 1 & $\begin{array}{c}0 \\
(1)\end{array}$ & 5 & $\begin{array}{c}0 \\
(4)\end{array}$ & 1 & 0 \\
\hline $\begin{array}{l}\text { Morone } \\
\text { americana }\end{array}$ & $\begin{array}{l}\text { White } \\
\text { perch }\end{array}$ & 2 & $\begin{array}{c}0 \\
(2)\end{array}$ & 1 & $\begin{array}{c}0 \\
(1)\end{array}$ & 1 & $\begin{array}{c}0 \\
(1)\end{array}$ & 0 & 0 \\
\hline $\begin{array}{l}\text { Mustelus } \\
\text { canis }\end{array}$ & $\begin{array}{l}\text { Smooth } \\
\text { dogfish }\end{array}$ & 0 & $\begin{array}{c}0 \\
(2)\end{array}$ & 0 & 0 & 5 & $\begin{array}{c}0 \\
(5)\end{array}$ & 2 & 0 \\
\hline $\begin{array}{l}\text { Centropristis } \\
\text { striata }\end{array}$ & $\begin{array}{c}\text { Black } \\
\text { sea bass }\end{array}$ & 0 & 0 & 0 & 0 & 1 & $\begin{array}{c}0 \\
(1)\end{array}$ & 0 & 0 \\
\hline $\begin{array}{l}\text { Astroscopus } \\
\text { guttatus }\end{array}$ & $\begin{array}{l}\text { Northern } \\
\text { stargazer }\end{array}$ & 1 & $0(1)$ & 0 & 0 & 0 & 0 & 0 & 0 \\
\hline \multirow[t]{2}{*}{ Total } & & 1030 & 5.6 & 1379 & 1.4 & 1466 & 14 & 333 & 23 \\
\hline & & & $(562)$ & & (587) & & (779) & & $(277)$ \\
\hline
\end{tabular}


Tethering experiments. To measure variation in predation risk during flounder settlement we performed weekly tethering experiments from May through midJune, 2002 using methods described in detail in Manderson et al. (2004). We selected 12 stations in sectors of the estuary (A, B, E, F) that serve as flounder settlement areas (Fig. 1, Table 1; Manderson et al. 2003). To minimize tangling artifacts we chose sites where woody and stone debris and attached vegetation were absent.

Winter flounder trawled in the NSBES were held in flow-through tanks supplied with seawater from Sandy Hook Bay $<7$ d before they were tethered. The tanks had $2 \mathrm{~cm}$ of fine sand substratum (grain diam. $=0.14$ $\mathrm{mm}$ ) and the fish were fed Artemia sp. nauplii and chopped clam ad libitum.

We tethered flounder 20 to $50 \mathrm{~mm}$ SL in the laboratory with monofilament ( $2.2 \mathrm{~kg}$ test, $75 \mathrm{~cm}$ long) using methods described in Manderson et al. (2004). Fish $<20 \mathrm{~mm}$ SL were too small to tether, while those $<60 \mathrm{~mm}$ are vulnerable to demersal fish predators in laboratory experiments (Manderson et al. 1999, 2000). The fish were tied rather than sewn to tethers to minimize tissue damage that can artificially attract predators (Curran \& Able 1998). Tethered fish recovered in the laboratory for $\sim 18 \mathrm{~h}$ before they were transported to the field in a cooler filled with aerated seawater.

We performed tethering on 2 consecutive days each week from May 8 through June 18 (6 stations $\left.\mathrm{d}^{-1}\right)$. Eight tethered fish were attached to snap swivels attached at $3 \mathrm{~m}$ intervals to $3 \mathrm{~mm}$ diam. chain that was staked to the substratum at each station by a diver. We set tethers $<4 \mathrm{~h}$ after sunrise. After $4 \mathrm{~h}$ we retrieved tethers and counted remaining fish. To avoid depleting predator fields, the trammel net surveys described above were performed $24 \mathrm{~h}$ after tethering.

We measured bottom temperatures, salinities, and depths at the stations during tether deployment and recovery. Divers collected bottom water that was measured for turbidity with a nephalometer (Hatch 2100p), and sediment samples $(2.5 \mathrm{~cm}$ diam., $\mathrm{n}=3)$ that were analyzed for grain size using sieve fractionation (Folk 1980). Divers also quantified bottom cover of habitat structures (shell, vegetation, polychaete and amphipod tubes) using replicate $(\mathrm{n}=3$ ) counts of $0.5 \mathrm{~m}$ quadrats with 25, $10 \mathrm{~cm}$ grid cells.

We applied analysis of deviance to nested logistic linear models to partition and test the significance $\left(\chi^{2}\right)$ of deviance in predation risk ( presence/absence of tethered fish) related to time, space at the 3 scales (region $[\sim 10 \mathrm{~km}]$, sector within region $[\sim 5 \mathrm{~km}]$, station within sector within region $[\sim 1 \mathrm{~km}]$; see Fig. 1), and space $\times$ time interactions (Venables \& Ripley 1997). Observations were weighted with the soak times of tethers which varied by $\pm 35 \mathrm{~min}$.
To quantify the relationship between predation risk and habitat characteristics we constructed a logistic GAM with the backward selection procedure used to model predator responses to temperature and salinity (see above). Independent variables considered were salinity, temperature, sediment grain size, percent cover of habitat structures, turbidity, depth, and abundance (CPUE) of Age-0 flounder and dominant predators. We also considered 'alternative prey' calculated as the combined abundance in trawls of Crangon septemspinosa and Palaemonetes spp. which occurred at high frequencies (16 to $80 \%$ ) in predators' diets.

\section{RESULTS}

\section{Physical characteristics}

Water temperatures (range $=6.8$ to $28.6^{\circ} \mathrm{C}$ ) were lowest in Sandy Hook Bay in spring (Days 100 to 153) and highest in the Navesink River in July and August (Days 183 to 245; Fig. 2). In spring and summer (Days 100 to 245 ) the river was typically 1 to $2^{\circ} \mathrm{C}$ warmer than the bay. We recorded unseasonably high temperatures in July 1999 (Days 183 to 214; 28.6 ${ }^{\circ} \mathrm{C}$ ) and late April and early May 2002 (Days 120 to 130; $18^{\circ} \mathrm{C}$ ) when the river was $\sim 5^{\circ} \mathrm{C}$ warmer than the bay. Winter 2002 was the warmest and driest in $107 \mathrm{yr}$ in the North Eastern US (see www.nrcc.cornell.edu/ climate/Summary_2002-Winter.html) and temperatures near the tip of Sandy Hook were 4 to $5^{\circ} \mathrm{C}$ above 5 yr daily averages in mid-April (1998 to 2002).

Salinity (range 9 to $31 \%$ ) was generally low in spring (Days 100 to 153) and high in late summer and fall (Days 200 to 312 ; Fig. 2). Salinity decreased upstream in all surveys (Spearman, rho $<-0.40, \mathrm{p}<0.001$ ), but bay and river salinities were typically most different during spring and early summer (Days 100 to $183 ; \bar{X}$ difference $=$ $2.0 \%$, 1.0 to $5.2 \%$ o). However, we measured unseasonably high salinities $>18 \%$ o throughout the river in April through mid-May 2002 (Days 110 to 136) when freshwater discharge from the Swimming River was the lowest in April and 5th lowest in May in 81 yr (Table 1; see http://nwis.waterdata.usgs.gov/nj/nwis/monthly/?site_n $\mathrm{o}=$ 01407500\&agency_cd = USGS).

\section{General patterns of predator occurrence and winter flounder consumption}

Gillnet collections (1998-9) were dominated by the pelagic fish, bluefish Pomatomus saltatrix (frequency of occurrence $[\mathrm{FO}]=46.7 \%$; median fork length [medFL] $=190 \mathrm{~mm}, 83$ to $760 \mathrm{~mm}$ ) and weakfish Cynoscion regalis; $(\mathrm{FO}=23 \%$; median total length 

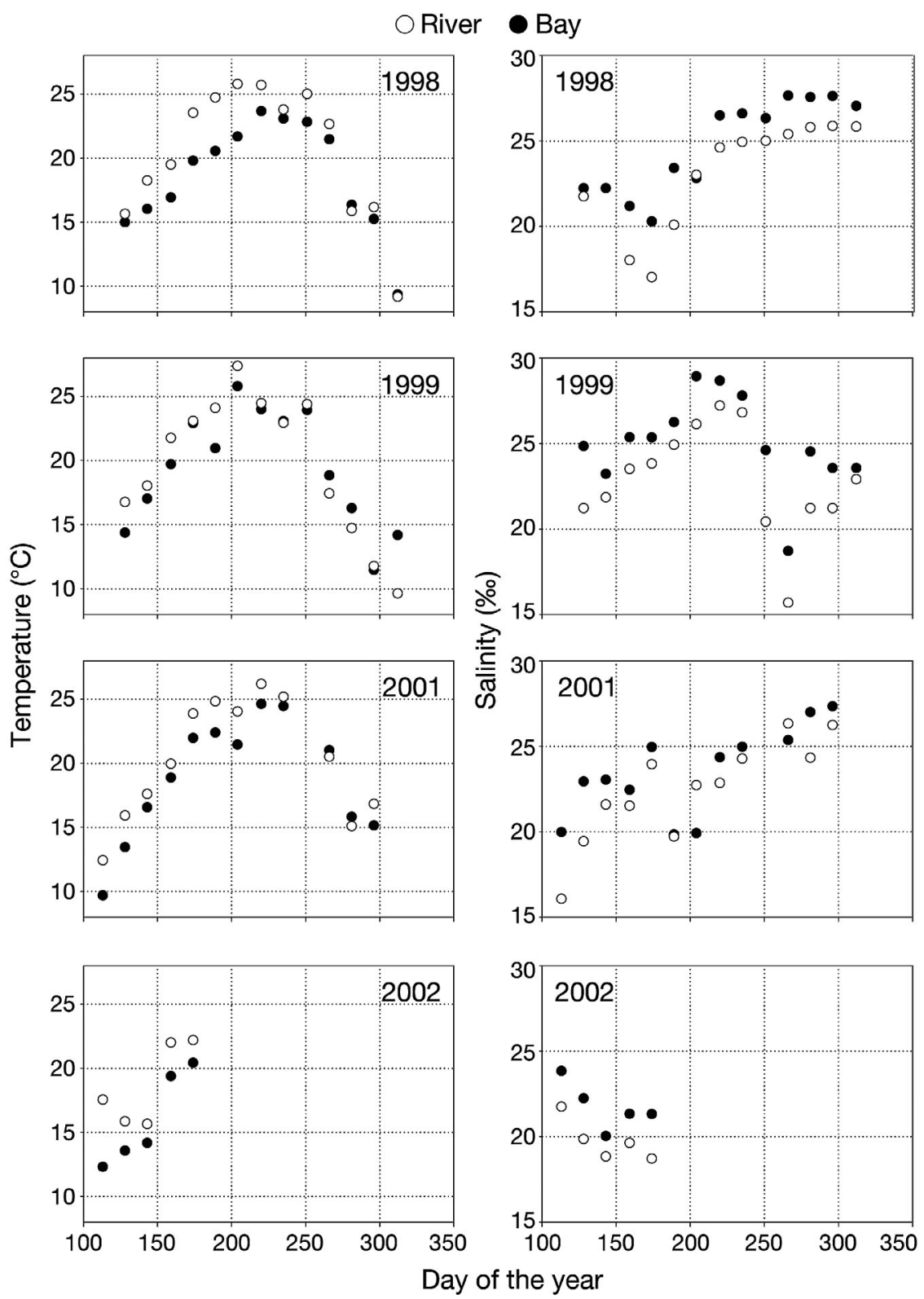

Fig. 2. Seasonal changes in mean temperatures and salinities measured in river and bay regions during gillnet (1998 and 1999) and trammel net (2001 and 2002) surveys

[medTL] $=235 \mathrm{~mm}, 95$ to $654 \mathrm{~mm}$; Table 2). Striped bass Morone saxatilis (FO $=11.5 \%$; medFL $=502 \mathrm{~mm}$, 114 to $448 \mathrm{~mm}$ ), striped searobin Prionotus evolans (FO $=9.5 \%$; $\operatorname{medTL}=226 \mathrm{~mm}, 32$ to $430 \mathrm{~mm}$ ), and summer flounder Paralichthys dentatus (FO $=6.2 \%$; medTL $=$ $357 \mathrm{~mm}, 280$ to $530 \mathrm{~mm}$ ) were also collected. In contrast with gillnets, trammel nets (2001 and 2002) collected large numbers of the demersal fish, striped searobin $(\mathrm{FO}=30.2 \%$; $\operatorname{medTL}=310 \mathrm{~mm}, 146$ to $437 \mathrm{~mm})$ and summer flounder $(\mathrm{FO}=27.8 \%$; medTL $=$ $342 \mathrm{~mm}, 67$ to $652 \mathrm{~mm})$. Bluefish $(\mathrm{FO}=5.6 \%$; medFL $=$ $520 \mathrm{~mm}, 170$ to $835 \mathrm{~mm})$, weakfish $(\mathrm{FO}=1.9 \%)$ and striped bass $(\mathrm{FO}=0.5 \%)$ were relatively rare in trammel nets.

Striped searobin, summer flounder, striped bass, weakfish, and bluefish consumed Age-0 winter flounder (12 to $70 \mathrm{~mm} \mathrm{SL;} \mathrm{Table} \mathrm{2).} \mathrm{Winter}$ flounder were frequent in striped searobin and summer flounder diets, particularly during the 2002 survey which ended in late June, shortly after flounder settlement. Winter flounder were rare in striped bass, bluefish, and weakfish stomachs.

\section{Predator distributions and typical patterns of predator-prey habitat overlap}

Distributions of flounder predators varied seasonally and upstream along the axis of the estuary (Fig. 3). Distance upstream, temperature, and day were included by backward selection in the DA of 1998 and 1999 gillnet data which was significantly different $(p=0.001)$ from randomized data in the Monte-Carlo test. The first canonical variate (CAN 1; 52\% of total dispersion, TD) represented upstream estuarine gradients. Seasonal temperature variations defined the second variate (CAN 2; $40 \%$ TD). Striped bass (CPUE: $\bar{x}=0.14 \mathrm{~h}^{-1}$, max. $=7.5 \mathrm{~h}^{-1}$ ) and searobins (CPUE: $\left.\bar{X}=0.19 \mathrm{~h}^{-1}, \max .=13.5 \mathrm{~h}^{-1}\right)$ were abundant in late spring (May to early June) when temperatures were cool and thus had high CAN 2 scores. Striped bass were most abundant upstream in the river and had a low CAN 1 score. Searobins were primarily collected downstream in the bay and thus had the highest CAN 1 score. Only a few searobins occurred in the river from late July through September 1999. Summer flounder (CPUE: $\bar{x}=0.04 \mathrm{~h}^{-1}$, $\max .=1.5 \mathrm{~h}^{-1}$ ) were present from late June through August in the inner bay and lower river. As a result, the predator had a low CAN 2 score and relatively high CAN 1 score. Bluefish (CPUE: $\bar{x}=2.55 \mathrm{~h}^{-1}, \max =$ $36.5 \mathrm{~h}^{-1}$ ) and weakfish (CPUE: $\bar{x}=0.57 \mathrm{~h}^{-1}$, $\max =$ $20.5 \mathrm{~h}^{-1}$ ) were common from July through early September in the river and had low scores on both variates.

The DA of 2001 and 2002 trammel net and beam trawl data indicated that Age-0 winter flounder were 

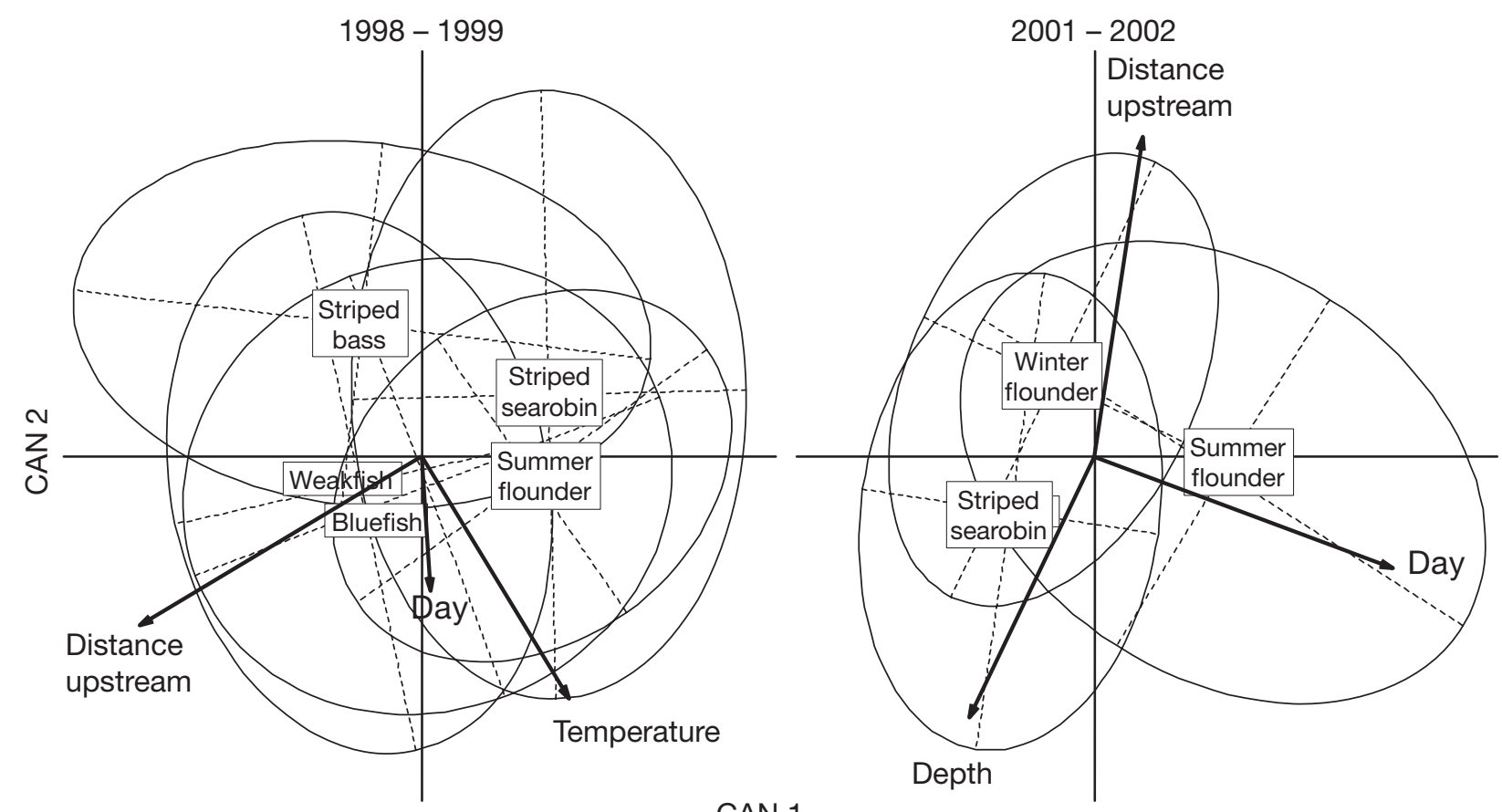

CAN 1

Fig. 3. Species centroids with inertia ellipses and cosines of canonical scores for independent variables (arrows) significant in stepwise discriminant analysis of winter flounder predators collected in gillnets in 1998 and 1999 and in trammel nets in 2001 and 2002, and winter flounder prey collected in beam trawls in 2001 and 2002. Searobin and summer flounder were generally more abundant in the lower estuary; thus, the upper estuary probably served as a spatial predator refuge for early juvenile winter flounder during most years. CAN = canonical axis

most likely to co-occur with searobins in deep bay habitats during the settlement period and with summer flounder later in the season in shallow habitats in the middle of the estuary (Fig. 3). Bluefish (CPUE: $\bar{x}=$ $\left.0.1 \mathrm{~h}^{-1}, \max .=9 \mathrm{~h}^{-1} ; \mathrm{FO}=5.6 \%\right)$ and weakfish $(\mathrm{CPUE}$ : $\bar{x}=0.01 \mathrm{~h}^{-1}$, max. $=1 \mathrm{~h}^{-1} ; \mathrm{FO}=1.9 \%$ ) were rare in trammel nets and analyses of 2001 and 2002 data were similar. As a result, we combined the 2 years to provide a summary of habitat overlap between searobin, summer flounder, and Age-0 winter flounder. Backward selection included day, distance upstream, and depth in the DA which was significantly different $(p=0.001)$ from randomized data in the Monte-Carlo test. The first canonical variate (CAN 1; $79 \%$ TD) was strongly related to day while the second variate (CAN 2; $21 \%$ TD) reflected upstream variations in habitat characteristics including depth. Searobins (CPUE: $\bar{x}=1.8 \mathrm{~h}^{-1}$, max. $=62.5 \mathrm{~h}^{-1}$ ) were collected during the first surveys in early May 2001 and late April 2002. The species reached peak abundance in mid-May during both years and had the lowest CAN 1 score. The predator was most abundant at deep sites in Sandy Hook Bay and had the lowest CAN 2 score. Searobins rarely occurred in the river in May and June 2001. In May 2002, however the predator was common in the river. Searobins appeared to occur in large groups as $21 \%$ of trammel nets containing the predator collected 10 or more individuals and $12 \%$ collected 20 or more. Summer flounder (CPUE: $\bar{x}=0.4 \mathrm{~h}^{-1}, \max .=10 \mathrm{~h}^{-1}$ ) were abundant later in the season (mid-June to mid-July) further upstream than searobins and had the highest CAN 1 and a low CAN 2 score. The predator was common in shallow habitats in the middle of the estuary. Summer flounder were not collected in large groups as only $15 \%$ of nets captured 5 or more individuals. Age- 0 winter flounder $(\mathrm{n}=308$, median $\mathrm{SL}=20 \mathrm{~mm}, 6$ to $143 ; \bar{x}$ CPUE $=0.2410 \mathrm{~m}^{-2}$, $\max .=810 \mathrm{~m}^{-2}$ ) reached peak abundance in early May and thus, like searobins, had a low CAN 1 score. Newly settled fish $<20$ mm SL were present in May and June 2001, and from late April through mid-June 2002. Winter flounder were most abundant in the river $(\bar{x} \mathrm{CPUE} \pm \mathrm{SE} ; 2001$ : river $0.30 \pm 0.07$, bay $0.06 \pm 0.01 ; 2002$ : river $0.61 \pm 0.11$, bay $0.20 \pm 0.01$ ) and had the lowest CAN 2 score.

\section{Distributions of dominant predators in relation to salinity and temperature}

Striped searobins were most likely to occur (probability $>0.5$ ) at salinities $>20 \%$ and temperatures of 12 to $22^{\circ} \mathrm{C}$, while summer flounder were common at temperatures $>24^{\circ} \mathrm{C}$ in the GAMs of trammel net collections made during flounder settlement (Fig 4; Table 3). 


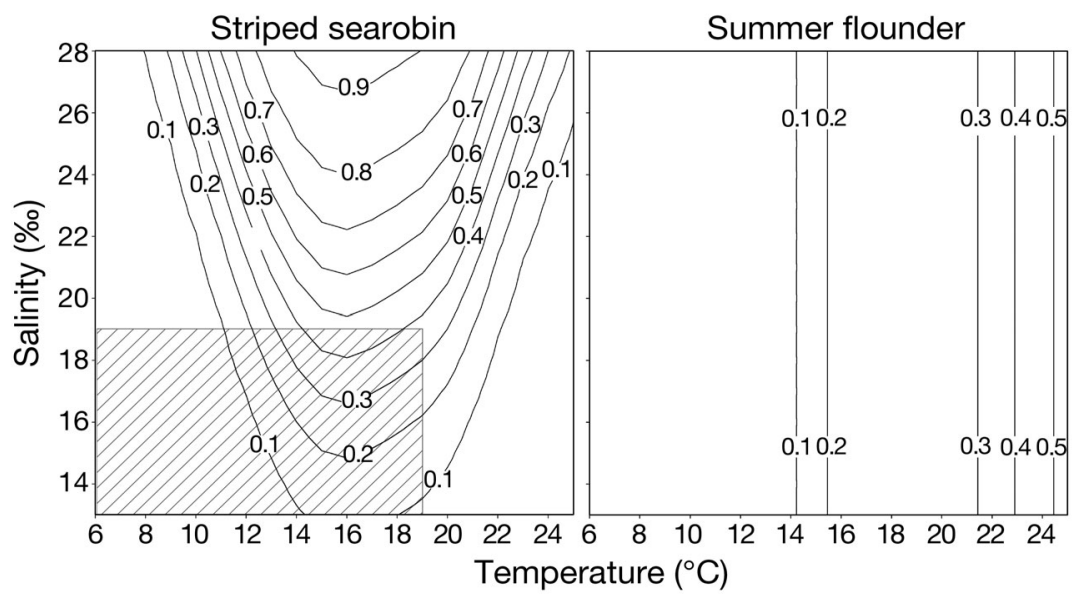

Fig. 4. Prionotus evolans and Paralichthys dentatus. Probabilities of occurrence for dominant demersal predators in relation to temperature and salinity during winter flounder settlement (late April to June) based on logistic generalized additive models (GAM) of trammel net collections in 2001 and 2002. Searobins were more likely to occur at cool temperatures and high salinities typically measured in the Sandy Hook Bay, while summer flounder were most likely to occur at warm temperatures (see Table 4). Hatched area on searobin plot indicates temperature and salinity combinations at which the survivorship of tethered winter flounder Pseudopleuronectes americanus was relatively high, based on the GAM of tethering data (see Table 4b, Fig. 8)

Table 3. Prionotus evolans and Paralichthys dentatus. Logistic generalized additive models of relationships between the occurrence of demersal predators and temperature and salinity during winter flounder Pseudopleuronectes americanus settlement from late April through June 2001 and 2002. Striped searobin were most likely to occur at high salinities and cool temperatures while summer flounder were most likely to occur at relatively high temperatures (see Fig. 4). Temperature term included in final model using a cubic spline smoother; otherwise the term was included as a linear term. $p<0.001$ in all cases

\begin{tabular}{|lcrrr|}
\hline $\begin{array}{l}\text { Species } \\
\text { Term }\end{array}$ & df & $\begin{array}{c}\text { Nonparametric } \\
\chi^{2}\end{array}$ & t-ratio & Coefficient \\
\hline Striped searobin & & & & \\
$\quad$ Intercept & 1 & & -4.92 & -6.98 \\
$\quad$ Salinity & 1 & & 4.64 & 0.30 \\
$\quad \begin{array}{l}\text { Temperature } \\
\text { \% total deviance explained }\end{array}$ & 3.87 & 38.1 & & \\
Summer flounder & 20.3 & & & \\
$\quad$ Intercept & 1 & & -5.07 & -1.95 \\
$\quad \begin{array}{l}\text { Temperature } \\
\text { \% total deviance explained }\end{array}$ & 3.76 & 19.7 & & \\
\hline
\end{tabular}

winter flounder (median $\mathrm{SL}=17 \mathrm{~mm}, 7$ to $70 \mathrm{~mm}, \mathrm{n}=369$, $\max$. $=13$ prey stom$\mathrm{ach}^{-1}$ ) in spring and early summer. This pattern was strong in early May 2001 and 2002 when many prey $<20 \mathrm{~mm}$ SL were eaten by searobins. During these years, searobin consumption of flounder peaked before the peak abundance of winter flounder in trawls. However, sizes of flounder in searobin diets were smaller than fish trawled indicating trawl bias toward larger sizes (2 sample Kolmogorov-Smirnov test $[D]=0.28$, $\mathrm{p}<<0.001)$. Searobins occasionally consumed flounder $>20 \mathrm{~mm}$ SL through mid-August. Striped bass consumed relatively large flounder (25 to $38 \mathrm{~mm} \mathrm{SL}$, $\mathrm{n}=3$ ) infrequently in May.

Summer flounder consumed larger winter flounder $(D=0.57, \mathrm{p}<<0.001$; median SL $=32 \mathrm{~mm}, 15$ to $60 \mathrm{~mm}, \mathrm{n}=69$, $\max =9$ prey stomach ${ }^{-1}$ ) later in the season than searobins (Fig. 5). Winter flounder first appeared in summer flounder diets in late May and most prey were $>20 \mathrm{~mm}$ SL. Summer flounder continued to eat the prey through August. Bluefish and weakfish ate relatively large flounder (median SL mm = 48, 25 to $56 ; \mathrm{n}=19$ ) infrequently in July and August.

Spatial patterns of winter flounder consumption generally reflected predator distributions (Fig. 6). In 1998 and 1999 and 2001 most flounder were eaten by searobins downstream in the bay. In May 2002, however, many prey were eaten by searobins collected in the middle and upper river. Summer flounder ate winter flounder in the inner bay and lower river. Striped bass, bluefish, and weakfish fed infrequently on the prey throughout the estuary.
Temperature $\times$ salinity interactions were not significant ( $p>0.05$ ) for either species, and summer flounder distributions were not related to salinity.

\section{Seasonal, spatial and size-dependent patterns of winter flounder consumption}

Winter flounder prey body sizes reflected seasonal patterns of predator occurrence and consumption (Fig. 5). Searobins fed on large numbers of newly settled

\section{Tethering assessment of winter flounder predation risk}

The survival of tethered flounder (total $\mathrm{n}=666$ ) averaged $57 \%$ and ranged from 25 to $87 \%$ in 7 experiments performed during the 2002 winter flounder settlement period. The median size of fish tethered was $36 \mathrm{~mm}$ SL and similar in most experiments. However, fish used in the 5th and 7th experiments were slightly larger (median SL $\mathrm{mm}=39$ and 38; ANOVA, df =6.679, $F=$ 19.8, $\mathrm{p}<0.001$ : Tukey pairwise test, $\mathrm{p} \leq 0.007$ ). 

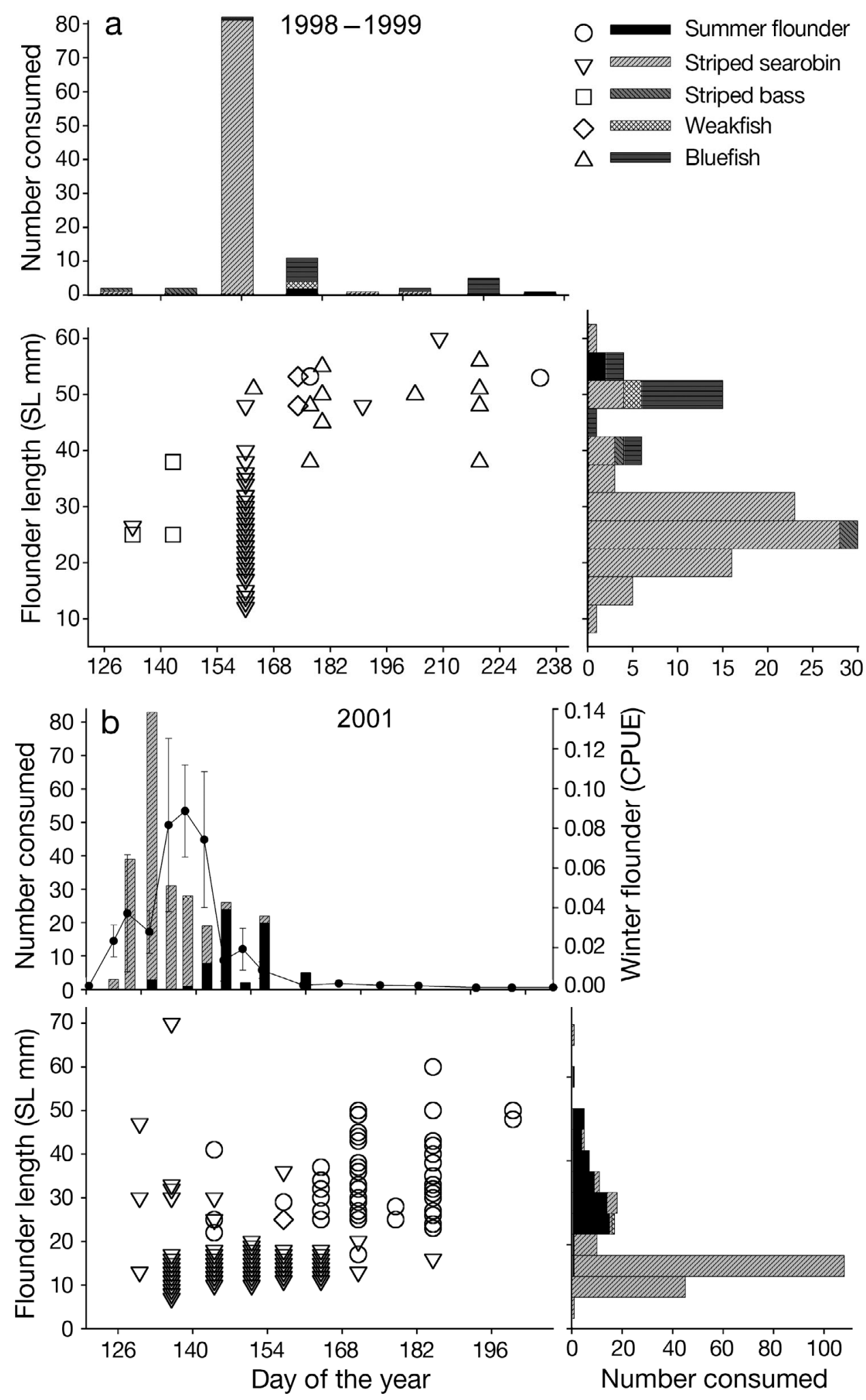

Fig. 5. (Above and overleaf) Pseudopleuronectes americanus. Seasonal and size-dependent patterns of winter flounder consumption by predators collected in (a) gillnets in 1998 and 1999, and in trammel nets in (b) 2001 and (c) 2002. Striped searobins consumed small recently settled flounder $<20 \mathrm{~mm}$ SL during May and early June, while summer flounder consumed postsettlement winter flounder $>20 \mathrm{~mm}$ SL in June and July. Striped bass, bluefish and weakfish ate post-settlement winter flounder $>20 \mathrm{~mm}$ SL infrequently. Temporal patterns of Age-0 winter flounder abundance measured in beam trawls are overlaid on upper panels in (b) and (c) 


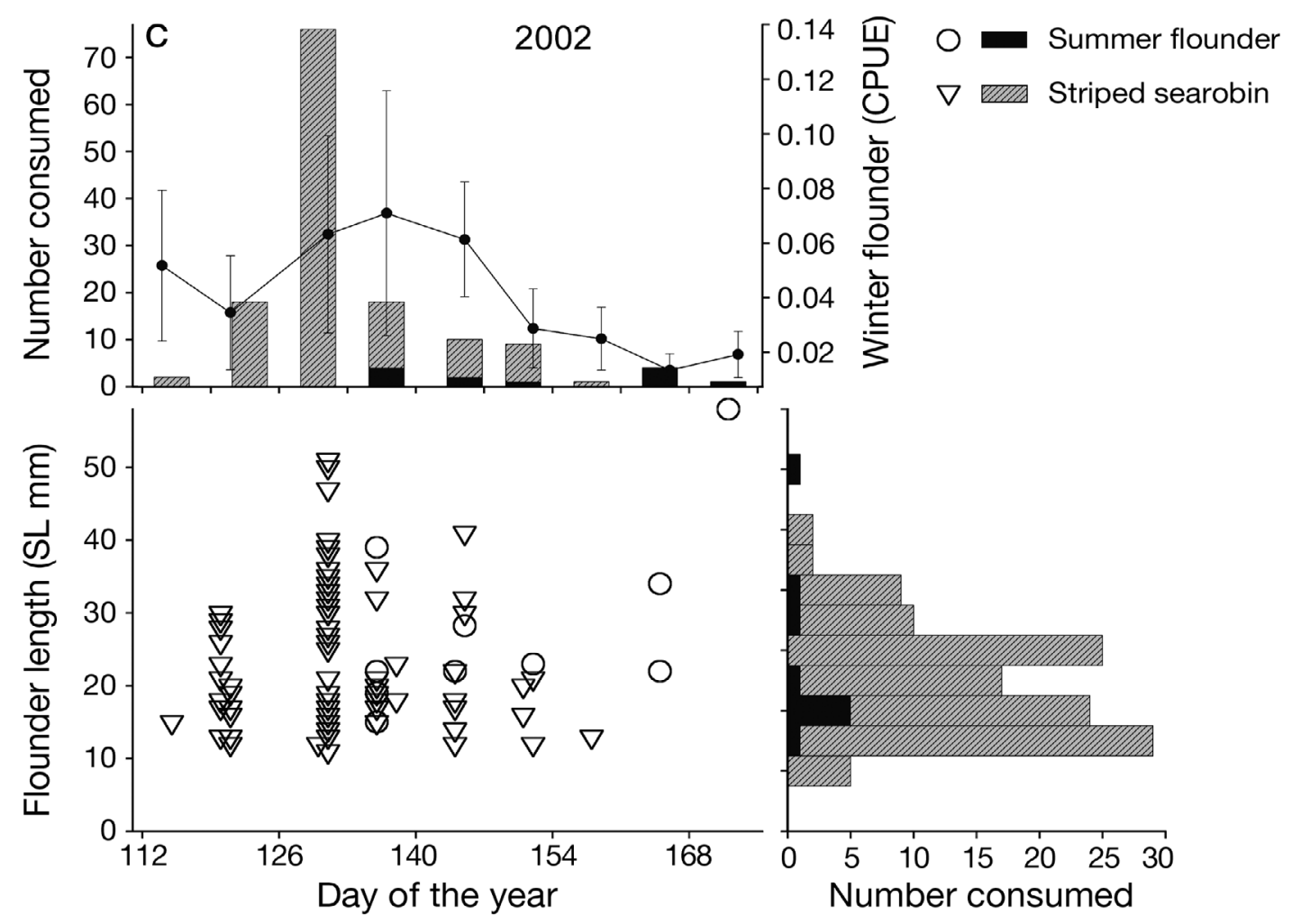

Fig. 5 (continued)

The survival of tethered fish was higher in the bay $(p=0.69 \pm 0.07)$ than in the river $(p=0.44 \pm 0.07$; Table $4 a$, Fig. 7). Survivorship varied significantly among regions, and differences were nearly significant $(p=0.06)$ among sectors within regions. Survival was high in the western part of the bay (Sector B: $p=0.87 \pm 0.08$ ) and low in the upper river (Sector $F: p=0.41 \pm 0.11$ ) where searobins with many flounder in their diets were collected (Fig. 6).

Survivorship was high at times and sites with moderate shell cover (10 to $30 \%$ ), salinities $<19 \%$, temperatures $<20^{\circ} \mathrm{C}$, and low sector-wide predator densities (Table 4b, Fig. 8). The cover of other habitat structures, turbidity, sediment grain size, and alternative prey densities did not affect survival ( $p>$ 0.05). Survival increased significantly with winter flounder abundance in trawls $\left(\chi^{2}=13.55, \mathrm{p}=0.003\right)$. However, we removed this variable from the final model because high flounder densities may have been an effect rather than a cause of high survivorship. Few tethered fish survived at Station 11 in
Table 4. Pseudopleuronectes americanus. (a) Analysis of deviance of nested general linear logistic models showing that tethered winter flounder survivorship varied significantly $(\mathrm{p}<0.05)$ between regions and that variation was nearly significant between sectors within regions (see Fig. 7). (b) Logistic generalized additive model showing that patterns of tethered winter flounder survivorship were related to variations in shell cover, salinity, temperature and the abundance of searobin and summer flounder predators at the sector scale (see Fig. 8). All terms used cubic spline smoothers. Npar chi: non-parametric Chi-square

\begin{tabular}{|lcccc|}
\hline (a) & & & & \\
Term & df & Deviance & $\mathrm{p}$ (chi) & \\
\hline Null model (includes intercept) & 665 & 116.57 & & \\
Experiment & 1 & 0.078 & 0.779 & \\
Region & 1 & 5.548 & 0.019 & \\
Sector(Region) & 2 & 5.736 & 0.057 & \\
Station(Sector[Region]) & 4 & 1.549 & 0.818 & \\
Experiment $\times$ Region & 1 & 0.070 & 0.791 & \\
Experiment $\times$ Sector(Region) & 2 & 0.424 & 0.809 & \\
Experiment $\times$ Station(Sector[Region]) & 4 & 0.787 & 0.940 & \\
Residual & 650 & 102.38 & & \\
(b) & & & & Deviance \\
Term & df & Npar chi & $\mathrm{p}$ & \\
& & & & \\
Shell & 2.9 & 39.24 & $<<0.001$ & 41.25 \\
Salinity & 3.0 & 16.13 & 0.001 & 17.10 \\
Temperature & 3.0 & 11.99 & 0.007 & 21.52 \\
Predator abundance (sector) & 2.8 & 9.96 & 0.016 & 20.55 \\
Independent effects & & & & 100.42 \\
Intercorrelated effects & & & & 38.13 \\
Total & & & & 772.52 \\
Residual & 649.3 & & & 911.07 \\
Null & 655 & & & \\
\hline
\end{tabular}



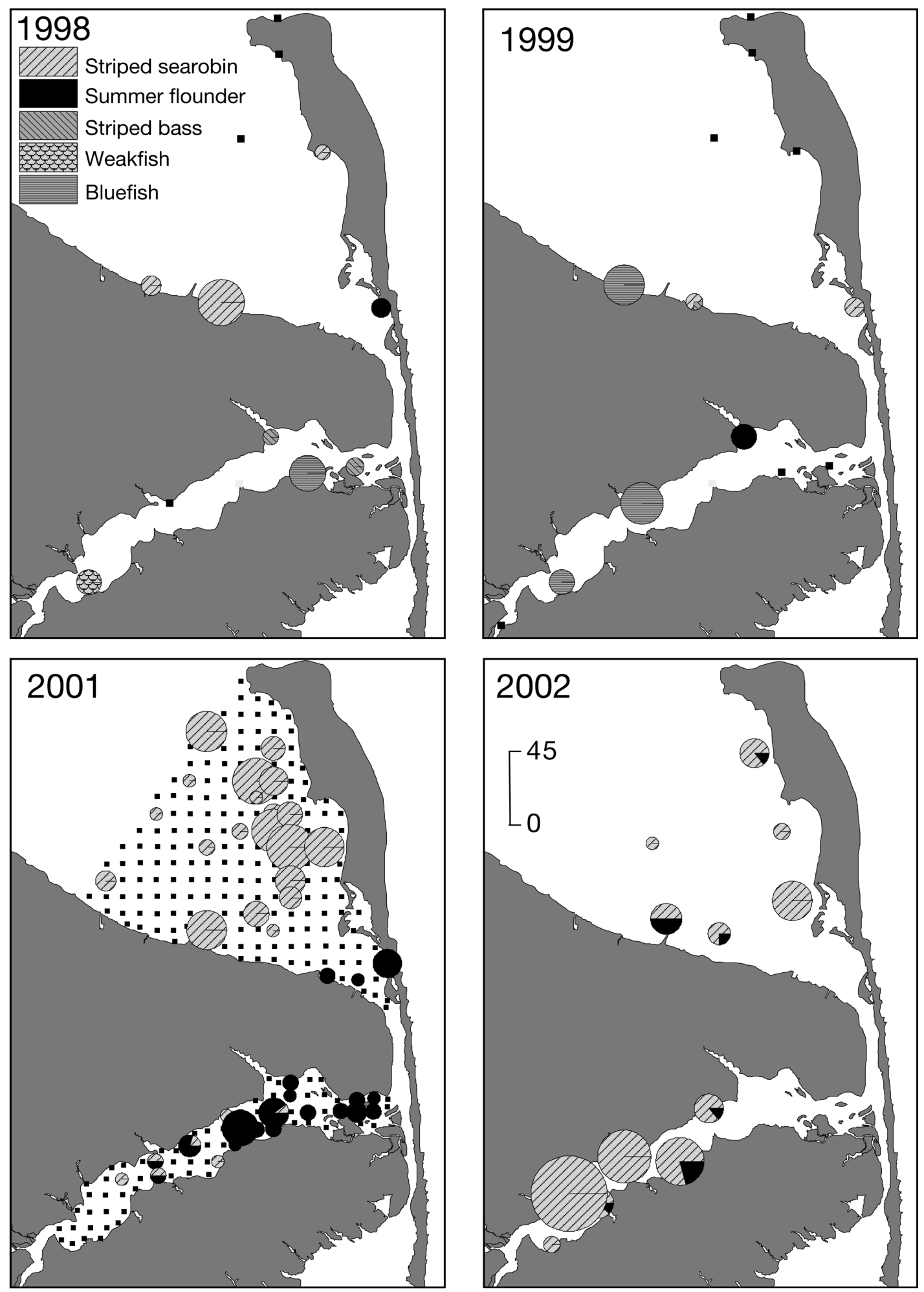

Fig. 6. Pseudopleuronectes americanus. Spatial patterns in numbers of juvenile winter flounder consumed by fish predators. Striped searobin generally consumed large numbers of recently settled winter flounder $<20 \mathrm{~mm}$ SL in Sandy Hook Bay, except in 2002 when many prey were eaten in the Navesink River. Summer flounder that fed on post-settlement winter flounder $>20 \mathrm{~mm}$ SL were primarily collected in the middle of the estuary, while weakfish, bluefish and striped bass ate the prey infrequently throughout the system. Symbol diameters represent the number of winter flounder and are scaled in the lower right panel.

(匹) Stations where predators with flounder in diets were not collected 


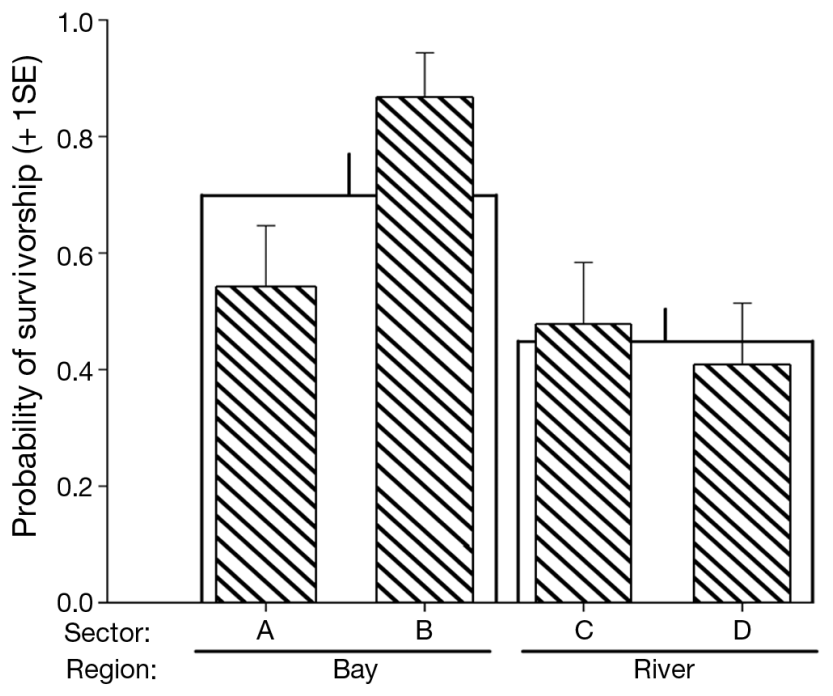

Fig. 7. Pseudopleuronectes americanus. Survivorship of tethered winter flounder. This was significantly higher $(p=0.019)$ in the bay than the river and differences were nearly significant among sectors within the 2 regions in 2002 (see Table 4a). Consistently low survivorship was measured in the western part of the Navesink River where searobins with large numbers of recently settled winter flounder in diets were also collected in trammel nets (see Fig. 6)
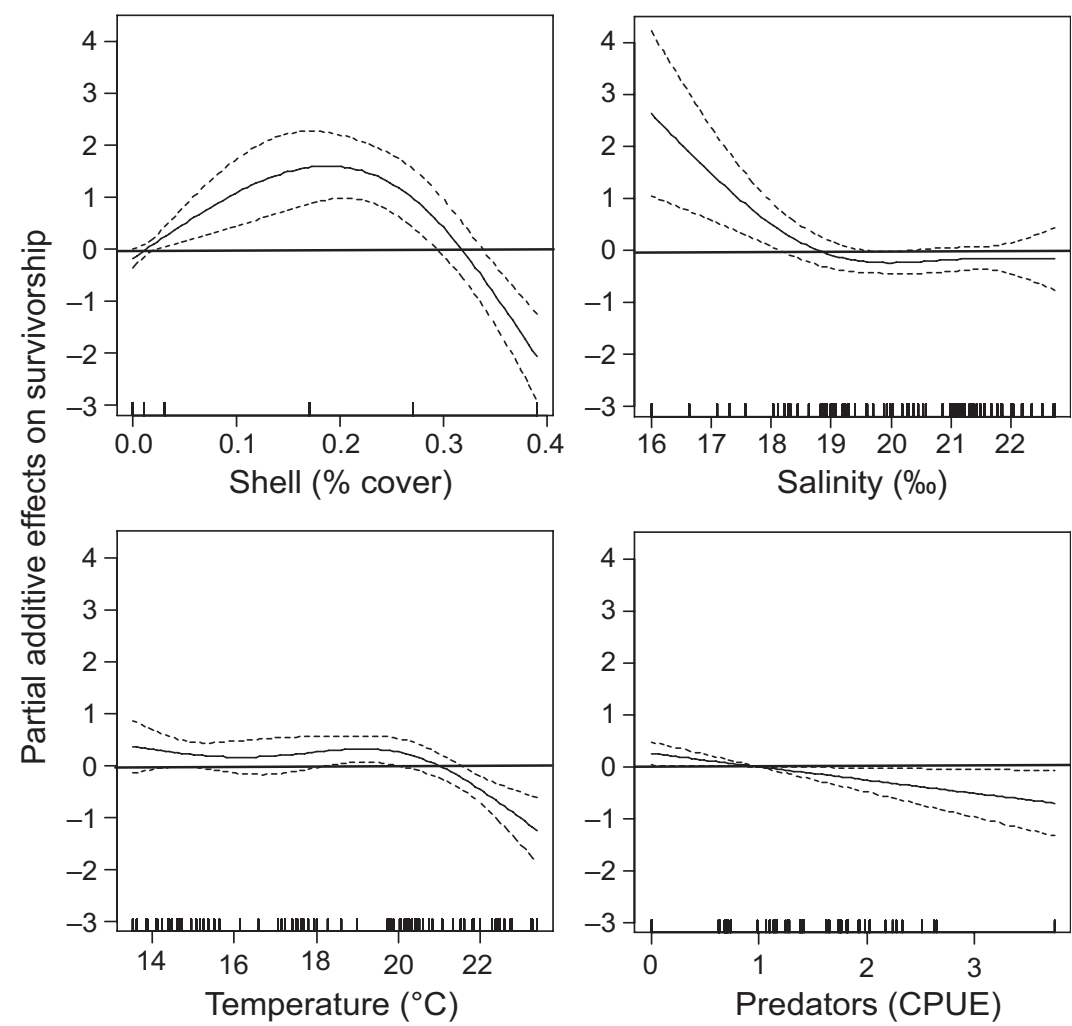

Fig. 8. Pseudopleuronectes americanus. Deviance plots derived from generalized additive model (GAM) indicating that the survivorship of tethered winter flounder was higher in habitats with moderate shell cover (\%), salinities $<19 \%$, temperatures $<21^{\circ} \mathrm{C}$ and in sectors where the abundance of predators (striped searobin and summer flounder) was relatively low (see Table 4b). 'Tick' marks on $x$-axis show the distribution of values for each independent variable the upper river where shell cover was high (>30\%), but searobins were abundant and consumed many flounder (Figs. 1 \& 6).

\section{DISCUSSION}

Populations of demersal fish, including flatfish, can be strongly regulated by mortality during the early post-settlement period when it is estimated that 30 to $85 \%$ of settlers are consumed by predators (van der Veer et al. 2000a, Almany \& Webster 2006). Most studies of early juvenile flatfish mortality have emphasized the role of crustacean predators (van der Veer et al. 2000a and references therein). Our study indicates that demersal fish, specifically striped searobin and summer flounder, may be important early juvenile winter flounpredators in an estuarine system where crustacean

is low (Manderson et al. 2003, Taylor 2005). Striped searobins fed upon large numbers of recthrough June, while summer flounder primarily consumed post-settlement stage fish $>20 \mathrm{~mm}$ in June and July. These seasonal and size dependent consumption patterns reflected differences in the timing of estuarine ingress of the 2 predators with respect to the timing of flounder settlement. Winter flounder larvae settle to benthic habitats in Mid-Atlantic Bight (MAB) estuaries including the NSBES from late April through June (Sogard et al. 2001, Manderson et al. 2003). Striped searobin migrate in the spring to $\mathrm{MAB}$ estuaries where they spawn beginning in May (Wilk et al. 1990, McBride 2002). Searobins occurred in our surveys in April and reached peak abundance in May when they fed upon large numbers of newly settled winter flounder. In contrast, summer flounder were abundant in the NSBES in late June and July when they fed on postsettlement staged prey. Summer flounder are generally most abundant in MAB estuaries in July and August when temperatures are warm (Packer et al. 1999 and references therein).

Although temporal differences in predator-prey habitat overlap primarily determined sizes of winter flounder consumed by striped searobins and summer flounder, sensory mechanisms used for prey detection may also have influenced size selection. Summer 
flounder rely on vision to detect prey, and winter flounder vulnerability to the predator increases linearly with increasing prey body size from 15 to $80 \mathrm{~mm}$ SL (Olla et al. 1972, Manderson et al. 2000). Searobins use pectoral finrays equipped with tactile and chemosensory receptors to search for and flush prey from sediments, and feed on smaller flounder (Silver \& Finger 1984, Manderson et al. 1999). Encounter rates of individual searobins with small flounder (30 to $40 \mathrm{~mm} \mathrm{SL}$ ) are also elevated when groups of predators use finrays to search for and flush prey from laboratory substrata (J. P. Manderson unpubl. data). Searobins appeared to aggregate in the field in May, when individual trammel nets frequently captured large numbers of searobins. Groups of foraging searobins could cause exceptionally high winter flounder mortality in habitats where the predator and prey co-occur.

Pelagic fish were abundant in the NSBES particularly in gillnet surveys, but we caught only a few pelagic predators with flounder $>25 \mathrm{~mm}$ SL in their diets. Flounder were probably rare in pelagic fish diets as a result of seasonal and vertical differences in habitat use. Bluefish and weakfish move into mid-Atlantic estuaries in large numbers in late June and July following flounder settlement and thus most newly settled winter flounder probably have a temporal refuge from the 2 predators (Able et al. 2003, Jung \& Houde 2003, Sharf et al. 2004, this study). Weakfish and bluefish also primarily feed upon pelagic prey including Brevoortia tyrannus, Menidia menida, Anchoa mitchilli and mysids (Hartman \& Brandt 1995, Lankford \& Targett 1997, Juanes et al. 2001, Buckel \& McKown 2002, Nemerson \& Able 2004) which are more abundant than juvenile flounder in the NSBES (Sharf et al. 2004, J. P. Manderson unpubl. data). Encounters of the predators with flounder are probably relatively rare irrespective of differences in vertical habitat use of pelagic predators, preferred pelagic prey and demersal flatfish prey. Although striped bass feed on demersal estuarine prey during spring and early summer (Buckel \& McKown 2002, Jordan et al. 2003), we collected just a few striped bass that had eaten flounder $\geq$ $25 \mathrm{~mm}$ SL in May when smaller newly settled winter flounder are much abundant (Stoner et al. 2001, Manderson et al. 2003, this study). Newly settled winter flounder may be relatively invulnerable to striped bass which, as visual predators, select larger prey (Scharf et al. 2003).

Most predators collected in gill and trammel nets were $>80 \mathrm{~mm}$ TL and $>230 \mathrm{~mm} \mathrm{TL}$, respectively, and smaller fish could also be important winter flounder predators. We did not capture juvenile spotted hake Urophycis regia (47 to $209 \mathrm{~mm}$ ) that occur in spring trawl surveys of Sandy Hook Bay and consume flounder 12 to $20 \mathrm{~mm}$ SL (J. P. Manderson unpubl. data).
Grubby sculpin Myoxocephalus aenaeus, oyster toadfish Opsanus tau, and windowpane flounder Scophthalmus aquosus are reported to feed on winter flounder, but we have not found the prey in these species diets in the NSBES (Pereira et al. 1999, this study, J. P. Manderson unpubl. data).

Our analyses of predator distributions and diets indicate that searobin predation pressure is usually high in winter flounder settlement habitats located downstream in Sandy Hook Bay, while summer flounder are probably an important source of mortality for postsettlement winter flounder in shallower habitats in the middle of the estuary. Searobins were usually most abundant in the bay, where they consumed the greatest numbers of newly settled winter flounder during most years. The predator was associated with relatively high salinities and cool temperatures normally found in deeper downstream areas in May and June which is consistent with observations in other estuaries (Pearcy \& Richards 1962, Martino \& Able 2003). Summer flounder are abundant in shallow sandy coastal habitats (see Packer et al. 1999 for review) and were relatively common in shallow areas in the inner part of Sandy Hook Bay and lower reach of the Navesink where they ate Age-0 winter flounder in June and July. These observations suggest that the upper estuary serves as a spatial refuge for settling flounder during most years. This conclusion is consistent with an earlier finding that mortality (and/or emigration) caused densities of settling flounder to decline at much lower rates in the Navesink River than in Sandy Hook Bay during the first few weeks following larval settlement (Manderson et al. 2003). Age-0 winter flounder are generally most abundant in upstream estuarine regions that, in some systems, have characteristics promoting early larval settlement and rapid early juvenile growth (Pearcy 1962, Armstrong 1997, Meng \& Powell 1999, Meng et al. 2001, Manderson et al. 2002, 2003). Our study indicates that habitat suitability for early juvenile winter flounder survivorship may also be high in upstream areas with specific environmental conditions.

The extent of an upstream predation refuge for winter flounder settling in the NSBES appeared to be controlled by the spatial structure of salinity, and to a lesser extent temperature, gradients in the estuary. From April through June, flounder predation risk and probability of searobin occurrence were both low at sites and times when salinities were $\leq 20 \%$ in independent GAMs of tethered fish survivorship and predator distributions. During springs with average to high freshwater discharge from the Swimming River, bottom salinities range from 14 to $16 \%$ in the middle and upper Navesink River during slack after flood tide when maximum salinities are recorded (Fugate \& Chant 2005, 
their Fig. 7). These conditions probably exclude searobins from the middle and upper river (Fig. 9). Flounder predation risk was also relatively low at cool temperatures $<20^{\circ} \mathrm{C}$. While searobins preferred cool temperatures, summer flounder were more likely to occur at warmer temperatures. During most years bottom temperatures in the river rarely exceed $15^{\circ} \mathrm{C}$ during the beginning of flounder settlement in April and early May (Manderson et al. 2003, this study, J. P. Manderson unpubl. data). Thus, in years of sufficient discharge and average spring warming, gradients in salinity, and to a lesser extent temperature, probably exclude both predators from the upper reaches of the estuary. This hypothesis is consistent with predator distributions and diets measured in 1998, 1999, and 2001 (in this study), spring trawl surveys (J. P. Manderson unpubl. data), and an earlier study of settlement and early post-settlement processes affecting winter flounder distributions in the NSBES (Manderson et al. 2003). In 2002, however, a severe spring drought and warm temperatures resulted in historically low freshwater discharge into the Navesink where salinities exceeded $18 \%$ and temperatures exceeded $18^{\circ} \mathrm{C}$ from late April through mid-
May. During this year winter flounder predation risk was high in the upper estuary where demersal predators, particularly searobins, were abundant and consumed many newly settled flounder. Historically low discharge produced a weak salinity gradient in the estuary during the 2002 winter flounder settlement period which appeared to result in a contraction of the upstream predation refuge (Fig. 9). Similar changes in fish distributions in response to changes in salinity gradient structure and freshwater discharge are common in estuaries (Jung \& Houde 2003, Hurst et al. 2004).

Predator and prey responses to dynamic temperature and salinity gradients in the estuary appeared to produce coarse scale gradients of predation risk and a region of low predation risk that may serve as a spatial refuge for newly settled winter flounder during most years. However within times and regions of predatorprey overlap fine scale structural habitat characteristics, such as depth and biogenic structure, including shell cover, that are nested within coarse scale gradients may modify encounter rates, predator attack success, and overall predation risk (Manderson et al. 2000, 2004, Stoner \& Titgen 2003). This appears to have been
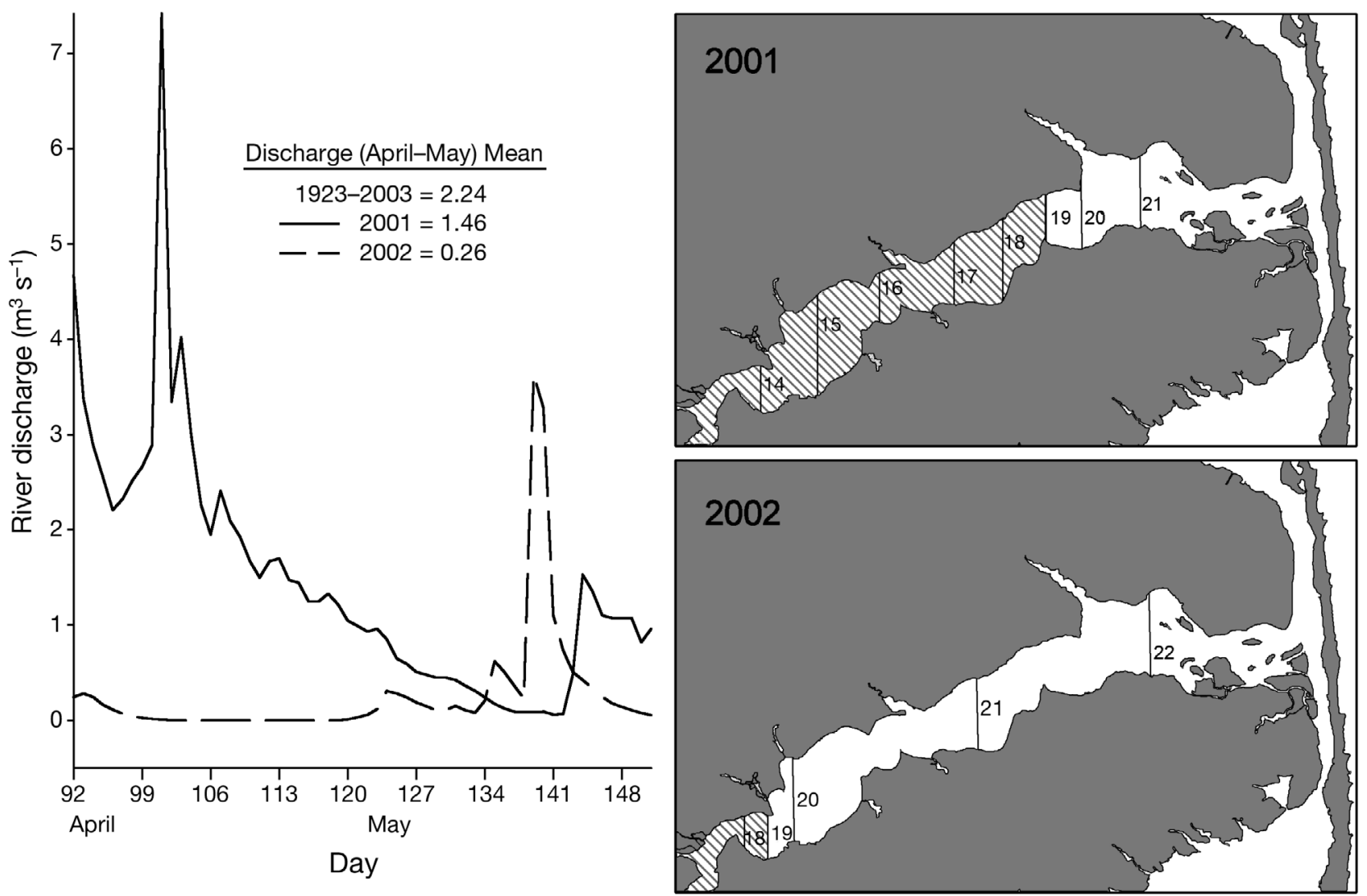

Fig. 9. Pseudopleuronectes americanus. Surface area of nursery habitat suitable for the survival of newly settled winter flounder (hatched area). This was probably much larger in 2001 than 2002 based on analysis of tethering experiments (Fig. 8), searobin occurrence (Fig. 4), Swimming River discharge (left panel) and the approximate spatial structure of the salinity gradient (numbered values) in the Navesink River (right panels) 
the case in our tethering experiments, as shell cover accounted for a significant portion of the deviation in winter flounder predation risk.

There are several potential artifacts associated with the timing of sampling and tethering that could have confounded our results. Piscivorous fish feeding and prey mortality show diel variations and are generally higher during dawn and dusk than day and night (Linehan et al. 2001, Holbrook \& Schmitt 2002, Clark et al. 2003). Summer flounder feed during the day and searobin predation on Age-0 winter flounder is higher during the day than at night in the laboratory (Olla et al. 1972, Manderson et al. 1999). It is possible that we would have observed different patterns in tethered fish mortality and predator consumption patterns if we had sampled at dusk. However, we believe our near dawn sampling occurred when predation rates on winter flounder are probably representative. There are also potential artifacts associated with tethering (addressed in detail in Manderson et al. 2004). However, unique to this study was our use of relatively large individuals to assess patterns of relative predation risk during flounder settlement when smaller fish are common. We were unable to successfully tether fish $<20 \mathrm{~mm}$ SL and acknowledge that survivorship patterns of small newly settled individuals may be somewhat different from those observed. However we selectively tethered flounder that fell within the size range of prey highly vulnerable to the dominant predators species (Manderson et al. 1999, 2000).

\section{CONCLUSIONS}

In a previous study, we demonstrated that winter flounder settled earlier in depositional habitats upstream in the Navesink River than in downstream Sandy Hook Bay habitats as a result of the combined effects of spatial variation in spring warming, circulation and substrate characteristics (Manderson et al. 2003). Recently settled juveniles also grew rapidly upstream for a limited period following settlement in response to dynamic temperature and salinity gradients as well as fine scale variations in prey density and dissolved oxygen (Manderson et al. 2002). The typical spring phenology and spatial structures of important habitat gradients appear to promote early larval settlement, rapid early juvenile growth and high early juvenile survivorship in the upstream reach of the estuary during most years. However, the present study suggests that variability in spring climatology which ultimately controls the spatial structures of physico-chemical gradients may cause the volume of suitable winter flounder nursery habitat to contract or expand. Interannual variation in recruitment is associated with sim- ilar changes in nursery habitat volumes for several species including white perch Morone americana (Kraus \& Secor 2005). Changes in the volume of suitable nursery habitat defined by rate regulating and spatially dynamic habitat characteristics could produce interannual variations in the production of winter flounder recruits.

Acknowledgements. We thank A. Drohan, C. Noji, W. Milligan, and J. Hilbert for their help in the field and laboratory. Special thanks go to J. Boreman, M. Fabrizio, R. Chant, B. Brainerd and anonymous reviewers for their valuable advice and reviews of the manuscript. This study complied with NOAA/NMFS regulations related to the care and husbandry of live animals.

\section{LITERATURE CITED}

Able KW, Rowe P, Burlas M, Byrne D (2003) Use of ocean and estuarine habitats by young-of-year bluefish (Pomatomus saltatrix) in the New York Bight. Fish Bull 101:201-214

Almany G, Webster M (2006) The predation gauntlet: early post-settlement mortality in reef fishes. Coral Reefs 25:19-22

Armstrong MP (1997) Seasonal and ontogenetic changes in distribution and abundance of smooth flounder Pleuronectes putnami, and winter flounder, Pleuronectes americanus, along estuarine depth and salinity gradients. Fish Bull 95:414-430

Bertram DF, Leggett WC (1994) Predation risk during the early life history periods of fishes: separating the effects of size and age. Mar Ecol Prog Ser 109:105-114

Buckel JA, McKown KA (2002) Competition between juvenile striped bass and bluefish: resource partitioning and growth rate. Mar Ecol Prog Ser 234:191-204

Clark KL, Ruiz GM, Hines AH (2003) Diel variation in predator abundance, predation risk and prey distribution in shallow-water estuarine habitats. J Exp Mar Biol Ecol 287:37-55

Curran MC, Able KW (1998) The value of tethering fishes (winter flounder and tautog) as a tool for assessing predation rates. Mar Ecol Prog Ser 163:45-51

Curran MC, Able KW (2002) Annual stability in the use of coves near inlets as settlement areas for winter flounder (Pseudopleuronectes americanus). Estuaries 25:227-235

Folk RL (1980) Petrology of sedimentary rocks. Hemphill Publishing, Austin, TX

Forrester GE, Steele MA (2004) Predators, prey refuges, and the spatial scaling of density-dependent prey mortality. Ecology 85:1332-1342

Fugate DC, Chant RJ (2005) Near bottom shear stresses in a small highly stratified estuary. J Geophys Res 110; C03022, doi:10.1029/2004JC002563

Hartman KJ, Brandt SB (1995) Predatory demand and impact of striped bass, bluefish, and weakfish in Chesapeake Bay: applications of bioenergetic models. Can J Fish Aquat Sci 52:1667-1687

Hixon MA, Jones GP (2005) Competition, predation, and density-dependent mortality in demersal marine fishes. Ecology 86:2847-2859

Holbrook SJ, Schmitt RJ (2002) Competition for shelter space causes density dependent predation mortality in damselfishes. Ecology 83:2855-2868 
Hurst TP, McKown KA, Conover DO (2004) Interannual and long-term variation in the nearshore fish community of the mesohaline Hudson River estuary. Estuaries 27:659-669

Jordan RC, Howe DV, Hurst TP, Juanes F (2003) Feeding habits of Age-0 striped bass, Morone saxatilis, in the midHudson River estuary: temporal, spatial, and ontogenetic variation. Estuaries 26:1486-1493

Juanes F, Buckel JA, Scharf FS (2001) Predatory behaviour and selectivity of a primary piscivore: comparison of fish and non-fish prey. Mar Ecol Prog Ser 217:157-165

Jung S, Houde ED (2003) Spatial and temporal variabilities of pelagic fish community structure and distribution in Chesapeake Bay, USA. Estuar Coast Shelf Sci 58:335-351

Kraus RT, Secor DH (2005) Application of the nursery-role hypothesis to an estuarine fish. Mar Ecol Prog Ser 291: 301-305

Lankford TEJ, Targett TE (1997) Selective predation by juvenile weakfish: post-consumptive constraints on energy maximization and growth. Ecology 78:1049-1061

Linehan JE, Gregory RS, Schneider DC (2001) Predation risk of Age-0 cod (Gadus morhua) relative to depth and substrate in coastal waters. J Exp Mar Biol Ecol 263:25-44

MacCall AD (1990) Dynamic geography of marine fish populations. University of Washington Press, Seattle, WA

Manderson JP, Phelan BA, Bejda AJ, Stehlik LL, Stoner AW (1999) Predation by striped searobin (Prionotus evolans, Triglidae) on young-of-the-year winter flounder (Pseudopleuronectes americanus, Walbaum): examining prey size selection and prey choice using field observations and laboratory experiments. J Exp Mar Biol Ecol 242:211-231

Manderson JP, Phelan BA, Stoner AW, Hilbert J (2000) Predator-prey relations between age $1+$ summer flounder (Paralichthys dentatus, Linnaeus) and age-0 winter flounder (Pseudopleuronectes americanus, Walbaum): predator diets, prey selection, and effects of sediments and macrophytes. J Exp Mar Biol Ecol 251:17-39

Manderson JP, Phelan BA, Meise C, Stehlik LL and 5 others (2002) Spatial dynamics of habitat suitability for the growth of newly settled winter flounder Pseudopleuronectes americanus in an estuarine nursery. Mar Ecol Prog Ser 228:227-239

Manderson JP, Pessutti J, Meise C, Johnson D, Shaheen P (2003) Winter flounder settlement dynamics and the modification of settlement patterns by post-settlement processes in a NW Atlantic estuary. Mar Ecol Prog Ser 253: 253-267

Manderson JP, Pessutti J, Hilbert JG, Juanes F (2004) Predation risk for a juvenile flatfish (winter flounder; Pseudopleuronectes americanus, Walbaum) in shallow water habitats. J Exp Mar Biol Ecol 304:137-157

Martino EJ, Able KW (2003) Fish assemblages across the marine to low salinity transition zone of a temperate estuary. Estuar Coast Shelf Sci 56:969-987

McBride RS (2002) Spawning, growth, and overwintering size of searobins (Triglidae: Prionotus carolinus and $P$. evolans). Fish Bull 100:641-647

Meng L, Powell JC (1999) Linking juvenile fish and their habitats: an example from Narragansett Bay, Rhode Island. Estuaries 22:905-916

Meng L, Powell JC, Taplin B (2001) Using winter flounder growth rates to assess habitat quality across an anthropogenic gradient in Narragansett bay, Rhode Island Estuaries 24:575-583

Murdoch WW, Avery S, Smyth MEB (1975) Switching in predatory fish. Ecology 56:1094-1105

Nemerson DM, Able KW (2004) Spatial patterns in diet and distribution of juveniles of four fish species in Delaware
Bay marsh creeks: factors influencing fish abundance. Mar Ecol Prog Ser 276:249-262

Olla BL, Samet CE, Studholme AL (1972) Activity and feeding behavior of the summer flounder (Paralichthys dentatus) under controlled laboratory conditions. Fish Bull 70: $1127-1136$

Overholtzer-McLeod KL (2004) Variance in reef spatial structure masks density dependence in coral-reef fish populations on natural versus artificial reefs. Mar Ecol Prog Ser 276:269-280

Packer DB, Griesbach S, Berrien PL, Zetlin C, Johnson DL, Morse WW (1999) Essential fish habitat source document: summer flounder, Paralichthys dentatus life history and habitat characteristics. NOAA Techl Memo NMFS NE-151

Pearcy WG (1962) Ecology of an estuarine population of winter flounder Pseudopleuronectes americanus (Walbaum). Parts I-IV. Bull Bingham Oceanogr Collect Yale Univ 18:1-77

Pearcy WG, Richards SW (1962) Distribution and ecology of fishes in the mystic river, Connecticut. Ecology 43: $248-259$

Pereira JJ, Goldberg R, Ziskowski JJ, Berrien PL, Morse WW Johnson DL (1999) Winter flounder, Pseudopleuronectes americanus, Life history and habitat characteristics. NOAA Tech Memo NMFS NE-138

Post JR, Parkinson EA, Johnston NT (1998) Spatial and temporal variation in risk to piscivory of Age-0 rainbow trout: patterns and population level consequences. Trans Am Fish Soc 127:932-942

R Development Core Team (2004) R:A language and environment for statistical computing. R Foundation for Statistical Computing, Vienna, Austria. (also available at: www.Rproject.org)

Scharf FS, Buckel JA, McGinn PA, Juanes F (2003) Vulnerability of marine forage fishes to piscivory: effects of prey behavior on susceptibility to attack and capture. J Exp Mar Biol Ecol 294:41-59

Scharf FS, Manderson JP, Fabrizio MC, Pessutti JP, Rosendale JE, Chant RJ, Bejda A (2004) Seasonal and interannual patterns of distribution and diet of bluefish within a middle Atlantic estuary in relation to abiotic and biotic factors. Estuaries 27:426-436

Silver WL, Finger TE (1984) Electrophysiological examination of a non-olfactory, non-gustatory chemosense in the searobin, Prionotus carolinus. J Comp Physiol A 154: 167-174

Sissenwine MP (1984) Why do fish populations vary? In: May RM (ed) Exploitation of marine communities. SpringerVerlag, Berlin, p 59-94

Sogard SM (1997) Size-selective mortality in the juvenile stage of teleost fishes: a review. Bull Mar Sci 60: 1129-1157

Sogard SM, Able KW, Hagan SM (2001) Long term assessment of settlement and growth of juvenile winter flounder (Pseudopleuronectes americanus) in New Jersey estuaries. Neth J Sea Res 45:189-204

Stoner AW, Titgen RH (2003) Biological structures and bottom type influence habitat choices made by Alaska flatfishes. J Exp Mar Biol Ecol 292:43-59

Stoner AW, Manderson JP, Pessutti JP (2001) Spatially explicit analysis of estuarine habitat for juvenile winter flounder: combining generalized additive models and geographic information systems. Mar Ecol Prog Ser 213:253-271

Taylor DL (2005) Predation on post-settlement winter flounder Pseudopleuronectes americanus by sand shrimp Crangon septemspinosa in NW Atlantic estuaries. Mar Ecol Prog Ser 289:245-262 
Taylor DL, Collie JS (2003) Effect of temperature on the functional response and foraging behavior of the sand shrimp Crangon septemspinosa preying on juvenile winter flounder Pseudopleuronectes americanus. Mar Ecol Prog Ser 263:217-234

van der Veer HW, Berghahn R, Miller JM, Rijnsdorp AD (2000a) Recruitment in flatfish, with special emphasis on North Atlantic species: progress made by the Flatfish Symposia. ICES J Mar Sci 57:202-215

van der Veer HW, Geffen AJ, Witte JIJ (2000b) Exceptionally strong year classes in plaice Pleuronectes platessa: are they generated during the pelagic stage only, or also in the juvenile stage? Mar Ecol Prog Ser 199:255-262

Venables WN, Ripley BD (1997) Modern applied statistics

Editorial responsibility: Otto Kinne (Editor-in-Chief),

Oldendorf/Luhe, Germany with S-Plus. Springer-Verlag, New York

Webster MS (2002) Role of predators in the early post-settlement demography of coral-reef fishes. Oecologia 131:52-60

Wennhage H, Pihl L (2001) Settlement patterns of newly settled plaice (Pleuronectes platessa) in a non-tidal Swedish fjord in relation to larval supply and benthic predators. Mar Biol 139:877-889

Wilk SJ, Morse WW, Stehlik LL (1990) Annual cycles of gonad-somatic indices as indicators of spawning activity for selected species of finfish collected from the New York Bight. Fish Bull 88:775-786

Wood SN, Augustin SN (2002) GAMs with integrated model selection using penalized regression splines and applications to environmental modelling. Ecol Model 157:157-177

Submitted: May 9, 2005; Accepted: May 2, 2006

Proofs received from author(s): November 24, 2006 